\title{
MENGKAJI LOGO GOJEK SOLV BERDASARKAN PERSEPSI DAN CITRA IDENTITAS VISUAL
}

\author{
Fardhan Mustagfier Abiyasa'), Muhammad Arya Sanjaya ${ }^{2)}$ \\ Program Studi Desain Komunikasi Visual, \\ Fakultas Bahasa dan Seni, Universitas Indraprasta PGRI \\ Jl. Nangka 58 C Tanjung Barat, Jakarta Selatan, 12530, Indonesia
}

Email: fardhanabiyasa@gmail.com

\begin{abstract}
Abstrak
Logo merupakan hal yang sangat penting untuk sebuah produk, perusahaan, dan organisasi. Logo sebagai identitas visual yang peran utamanya menunjukan, memperlihatkan, dan mengekspresikan kepribadian brand atau perusahaan kepada khalayak masyarakat atau taget sasaran yang dituju. Desain bentuk, komposisi warna, tipografi, dan simbol visual merupakan beberapa elemen yang terdapat dalam sebuah logo. Logo memuat pesan yang mampu membentuk persepsi dan citra sesuai dengan visi misi dan tujuan perusahaan. Tujuan penelitian ini adalah untuk mengetahui persepsi dan citra pada sebuah logo Gojek, seperti apa persepsi dan citra yang ingin ditunjukan perusahaan tersebut. Metode yang digunakan dalam penelitian ini adalah deskriptif kualitatif dengan menggunakan angket kuesioner yang berisikan pernyataan mengenai logo Gojek. Hasil jawaban pertanyaan angket kuesioner tersebut akan dianalisa secara deskriptif, sehingga dihasilkan sebuah kesimpulan bahwa logo Gojek berhasil mewakili apa yang ingin disampaikan perusahaan Gojek. Logo Gojek berhasil menyampaikan Identitas perusahaannya sehingga tercipta citra yang baik dan sesuai di dalam benak stakeholder atau pelanggan.
\end{abstract}

Kata Kunci: Logo, Persepsi, Citra, Identitas Visual

\begin{abstract}
Logo is very important for a product or company or organization, because the logo is a visual identity whose main role is to show, show, and express the personality of their brand or company to the public or target audience they are aiming for. logo as a product or company identity that has a design shape, color composition, typography, and visual symbols are some of the elements contained in a logo and this message is finally able to shape the perceptions that are formed in the minds of customers and a company image that is in accordance with the vision and mission and the purpose of the company. The purpose of this study was to determine perceptions and images on a Gojek logo like what perceptions and images you want to show from the company. The method used in this research is descriptive qualitative using a questionnaire containing a statement about the Gojek logo. The results of the questionnaire questionnaire answers will be analyzed descriptively, so that a conclusion is generated that the Gojek logo successfully represents what the Gojek company wishes to convey in its logo. The Gojek logo successfully conveyed the identity of the company so as to create a good and appropriate image in the minds of stakeholders or customers.
\end{abstract}

Keywords: Logo, Perception, Image, Visual Identity

Correspondence author: Fardhan Mustagfier Abiyasa, fardhanabiyasa@ gmail.com, Jakarta, and Indonesia 


\section{PENDAHULUAN}

Logo menjadi salah satu hal yang mendasar sebagai identitas atau tanda pengenal sebuah perusahaan, logo dapat membedakan dan memberikan ciri khas perusahaan, organisasi, atau produk satu dengan yang lainnya. Logo diartikan sebagai segala sesuatu yang berupa lambang, gambar, tulisan, angka, atau gabungan dari berbagai hal tersebut, yang disandang oleh suatu produk, perusahaan, lembaga, organisasi, atau kegiatan, untuk mencirikan suatu eksistensinya agar dapat dibedakan dari produk atau merek lain (Sudiana, 1999). Baik berupa gambar maupun tipografi, terdapat filosofi, visi dan misi dari perusahaan. Melalui logo, perusahaan dapat memiliki sasaran dan tujuan yang efektif sehingga akan dikenal oleh publik dan pada akhirnya menciptakan citra positif atas jati dirinya. Persaingan pasar yang semakin ketat serta segmen pasar yang sama menuntut sebuah perusahaan membuat logo dengan tepat dan menarik bagi masyarakat. Tujuan lain dari sebuah logo adalah sebagai tanda pengenal cepat akan sesuatu yang merupakan milik sebuah perusahan. Apabila suatu logo dinilai tidak tepat, maka dapat menjatuhkan sebuah lembaga atau perusahaan tersebut atau bisa dikatakan akan kalah saing. Dengan demikian logo berperan penting bagi perusahaan atau lembaga.

Identitas visual berfungsi untuk membangun dan membentuk pengenalan serta perhatian akan merek tersebut, sehingga dapat mudah dikenali dan diingat. Identitas visual suatu merek memicu dan menimbulkan persepsi dan asosiasi terhadap merek tersebut (Wheeler, 2003). Wheeler (2003) memaparkan bahwa urutan dan proses pengenalan terhadap visual logo adalah dimulai dari bentuk. Mengakui, mengenal dan mengingat bentuk suatu visual adalah tahap awal dan paling mendasar dari otak manusia. Visual berupa gambar dapat diingat, dikenal dan diakui secara langsung dan tentunya suatu bentuk gambar visual yang unik dan khas dapat dikenal dan diingat dengan lebih cepat. Kedua adalah warna, dapat memicu emosi dan membangkitkan asosiasi terhadap suatu merek. Suatu warna yang unik pada suatu merek, tidak hanya untuk membangun kesadaran akan merek tersebut tetapi juga untuk mengekspresikan diferensiasi atau perbedaan dengan merek lainnya. Ketiga adalah konten atau isi keseluruhan, yaitu proses mengenal, mengingat dan memahami dengan melihat secara keseluruhan elemenelemen visual yang terdapat pada suatu visual logo.

Persepsi adalah pengalaman tentang suatu objek, peristiwa atau suatu hubungan yang diperoleh dengan menyimpulkan informasi dan menafsirkan pesan. Persepsi dipengaruhi oleh beberapa faktor seperti perhatian, fungsional dan struktural (Atsar, 2014). Persepsi setiap orang tentu berbeda-beda, akan tetapi apabila perancangan logo sangat tepat atau berhasil, dapat membuat masyarakat mempunyai satu persepsi yang sama sehingga logo benar-benar berfungsi secara optimal dan identitas perusahaan dibalik visual logo dapat terekam di benak masyarakat.

Citra perusahaan atau corporate image adalah bagaimana suatu perusahaan atau lembaga dilihat dan dipersepsikan oleh masyarakat. Suatu citra yang positif tentang jati diri perusahaan atau lembaga dapat dibangun melalui logo. Dengan kata lain logo adalah sesuatu yang menunjukan eksistensi suatu perusahaan atau lembaga (Martadi, 2002). Jika organisasi tidak menyukai citra yang ada pada khalayaknya, organisasi atau perusahaan bisa mengubahnya, tetapi tidak demikian halnya dengan identitas, identitas tidak bisa diubah karena identitas adalah manifestasi visual kenyataan organisasi yang terlihat pada logo, produk, bangunan, seragam karyawan atau benda-benda lain yang digunakan organisasi atau perusahaan, dan yang dibuat oleh organisasi untuk berkomunikasi dengan khalayaknya. Keberadaan logo sangat erat kaitannya dengan citra perusahaan. Biasanya orang-orang mampu menilai seperti apa kualitas atau keprofesionalan sebuah perusahaan hanya dengan melihat logo dari perusahaan tersebut. Dapat diartikan bahwa citra perusahaan bukan hanya usaha yang dibentuk dari dalam perusahaan tetapi utamanya adalah yang terbentuk di luar perusahaan ketika perusahaan tersebut berinteraksi dengan masyarakat. Faktor masyarakat dalam kaitan visual adalah sebagai pembaca teks dari kumpulan tanda-tanda yang diciptakan dari dalam perusahaan, dan juga sebagai penerima yang merasakan jasa yang diberikan oleh perusahaan.

Identitas perusahaan adalah manifestasi aktual dari realita perusahaan seperti yang disampaikan melalui nama perusahaan, logo, moto, produk, layanan, bangunan, alat-alat tulis, seragam dan barang-barang bukti nyata yang diciptakan oleh organisasi tersebut dan 
dikomunikasikan kepada beragam konstituen. Konstituen kemudian membentuk persepsi berdasarkan pesan-pesan yang perusahaan tersebut kirimkan dalam bentuk nyata. Jika citra-citra ini dengan akurat mencerminkan realita perusahaan, program identitas tersebut berhasil. Dan jika persepsi berbeda sekali dengan realita, maka strateginya tidak efektif atau pemahaman perusahaan tersebut membutuhkan modifikasi (Argenti, 2010). Citra dan identitas menentukan kuat atau lemahnya reputasi perusahaan. Identitas perusahaan adalah hal yang sepenuhnya merupakan citra perusahaan. Identitas perusahaan yang kuat menghasilkan kepercayaan orang banyakterhadap nilai dan produk perusahaan. Reputasi perusahaan akan meningkat dan pada gilirannya ini akan membantu meningkatkan identitas perusahaan.

Elemen yang terdapat dalam sebuah logo seperti desain bentuk, komposisi warna, tipografi, dan simbol visual memiliki filosofi dan maksud tersendiri pada setiap elemennya sehingga pesan dapat disampaikan perusahaan kepada publiknya. Pesan inilah yang akhirnya dapat membentuk persepsi dan citra identitas perusahaan. Keberadaan logo sangat erat kaitannya dengan citra perusahaan. Biasanya khalayak mampu menilai seperti apa kualitas atau keprofesionalan sebuah perusahaan dengan hanya melihat logo dari perusahaan tersebut. Identitas perusahaan tidak terlepas dari citra yang melekat pada perusahaan itu. Sulit untuk mengklasifikasikan citra dan identitas sebagai subfungsi yang terpisah dalam fungsi komunikasi korporat, karena citra adalah realitas organisasi.

Pada tanggal 22 Juli 2019 Gojek resmi meluncurkan logo barunya dengan nama Solv. Perubahan logo ini merupakan tonggak sejarah baru yang menandai evolusi Gojek dari layanan ride-hailing, menjadi sebuah ekosistem terintegrasi yang menggerakkan orang, barang, dan uang. Gojek adalah perusahaan penyedia jasa pemesanan ojek yang menggunakan teknologi aplikasi android. Gojek didirikan oleh Nadiem Makarim dan Michaelangelo Moran, Gojek mulai beroperasi di Jakarta sejak tahun 2011. Pada awal berdirinya, Gojek hanya melayani pesanan ojek melalui telepon genggam namun sejak bulan Januari 2015, Gojek telah meluncurkan aplikasi ponsel yang dapat digunakan sebagai media pemesanan moda transportasi tersebut. Aplikasi Gojek dapat diunduh melalui smartphone baik android dan Ios (Amajida, 2016). Tujuan kajian ini adalah untuk mengetahui persepsi dan citra yang terbentuk di benak khalayak terhadap identitas logo Gojek tersebut.

\section{METODE PENELITIAN}

Pendekatan yang digunakan dalam penelitian ini adalah pendekatan deskriptif kualitatif. Penelitian deskriptif kualitatif adalah penelitian yang bermaksud untuk memahami fenomena tentang apa yang dialami oleh subjek penelitian, misalnya perilaku, persepsi, motivasi, tindakan, dll, secara holistik dan dengan cara deskripsi dalam bentuk kata-kata dan bahasa, pada suatu konteks khusus yang alamiah dan dengan memanfaatkan berbagai metode alamiah (Moleong, 2007). Dalam awal penelitian, peneliti terlebih dahulu melakukan telaah tentang logo sebagai identitas sesuai dengan bentuk dan warna pada logo Gojek.

Metode penelitian ini menggunakan analisis deskriptif dengan menggunakan artikel dan jurnal ilmiah yang di dapat dari internet serta metode noninteraktif meliputi teknik kuesioner dalam menyimpulkan penelitian ini. Metode noninteraktif meliputi observasi takberperanserta, teknik kuesioner, mencatat dokumen, dan partisipasi tidak berperan (Sutopo, 2006). Kuesioner merupakan daftar pertanyaan bagi pengumpulan data dalam penelitian. Dalam penelitian kualitatif, teknik kuesioner lazimnya digunakan sebagai langkah awal dalam pengumpulan data penelitian (Nugrahani \& Hum, 2014). Angket kuesioner akan berisikan pernyataan-pernyataan konsep makna bentuk, warna, tipografi dan penampilan keseluruhan logo, yang ditujukan kepada stakeholder sebanyak 30 responden masyarakat umum. Hasil jawaban pernyataan angket kuesioner tersebut akan dianalisa secara deskriptif.

Penelitian ini akan mengkaji logo dengan menggunakan konsep indentitas visual pada logo yaitu konsep bentuk, tipografi dan warna. Selanjutnya akan dilakukan analisa tanggapan dan persepsi pada logo dengan menggunakan teknik kuesioner yang berisi pernyataanpernyataan konsep makna bentuk, warna dan penampilan keseluruhan logo baru Gojek yang bernama Solv, sehingga dihasilkan kesimpulan yang menjawab tujuan penelitian ini. 


\section{HASIL DAN PEMBAHASAN}

Pada tanggal 22 Juli 2019 Gojek resmi meluncurkan logo barunya dengan nama Solv. Logo tersebut diberi nama Solv, diambil dari kata bahasa Inggris Solve yang berarti memecahkan masalah. Perubahan logo ini merupakan tonggak sejarah baru yang menandai evolusi Gojek dari layanan ride-hailing, menjadi sebuah ekosistem terintegrasi yang menggerakkan orang, barang, dan uang. Gojek adalah perusahaan penyedia jasa pemesanan ojek yang menggunakan teknologi aplikasi android. Gojek didirikan oleh Nadiem Makarim dan Michaelangelo Moran, Gojek mulai beroperasi di Jakarta sejak tahun 2011. Pada awal berdirinya, Gojek hanya melayani pesanan ojek melalui telepon genggam namun sejak bulan Januari 2015, Gojek telah meluncurkan aplikasi ponsel yang dapat digunakan sebagai media pemesanan moda transportasi tersebut. Aplikasi Gojek dapat diunduh melalui smartphone baik android dan Ios (Amajida, 2016).

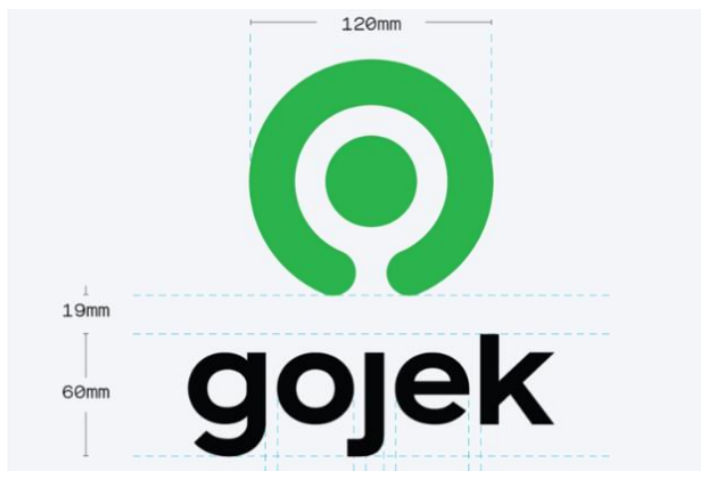

Gambar 1 Logo Gojek Solv

Sumber foto: tekno.kompas.com

Logo Gojek masuk ke dalam kategori Logogram and separate type (gabungan gambar dan tulisan terpisah). Logo jenis ini merupakan penggabungan antara jenis gambar dan tulisan. Pada logo jenis ini, gambar dan tulisan terpisah, akan tetapi satu sama lain saling menguatkan untuk menghadirkan makna dari tujuan logo tersebut (Nasution, 2017).

A. Makna Konsep Bentuk Logo Gojek "Solv"

1. Bentuk lingkaran tidak sempurna dengan titik di tengah seperti bentuk tombol power, melambangkan misi Gojek yaitu memberdayakan masyarakat

2. Bentuk logo seperti ikon fungsi pencarian (search), melambangkan Gojek dalam memenuhi kebutuhan yang banyak dicari seperti transportasi sampai makanan

3. Bentuk logo seperti seorang yang sedang memeluk, melambangkan Gojek peduli kepada pengguna

4. Bentuk logo menyerupai titik penanda seperti aplikasi peta digital melambangkan Gojek hadir dimanapun

5. Huruf kecil melambangkan, sikap ramah dan rendah hati, yaitu ramah terhadap semua segmen bisnis yang dimasuki, menunjukkan keinginan yang besar untuk melayani dengan rendah hati (Clinten, 2019).

B. Makna Konsep Warna Logo

Warna hijau pada logo melambangkan kesegaran dan pertumbuhan, seperti Gojek yang merupakan sebuah inovasi (Clinten, 2019).

C. Analisis Tanggapan dan Persepsi Terhadap Logo Gojek Solv

1. Tanggapan dan Persepsi Stakeholder Terhadap Bentuk Logo

a. Bentuk lingkaran tidak sempurna dengan titik ditengah seperti bentuk tombol power melambangkan misi Gojek yaitu memberdayakan masyarakat 


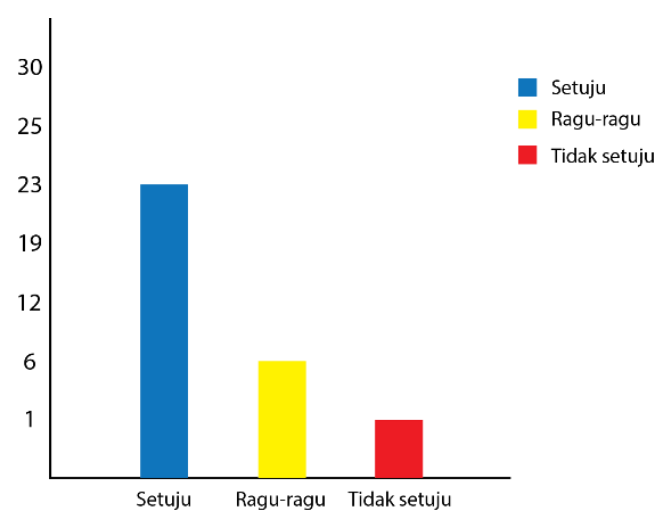

Berdasarkan tabel di atas dapat diketahui bahwa mayoritas responden menyatakan setuju yakni sebanyak 23 orang atau $76,6 \%$, sedangkan yang paling sedikit menyatakan tidak setuju yakni sebanyak 1 orang atau 3,3\%. Hasil tanggapan tersebut membuktikan mayoritas responden setuju dengan persepsi bahwa bentuk lingkaran tidak sempurna dengan titik ditengah seperti bentuk tombol power melambangkan misi Gojek yaitu memberdayakan masyarakat.

b. Bentuk logo seperti ikon fungsi pencarian (search) melambangkan Gojek dalam memenuhi kebutuhan yang banyak dicari seperti transportasi sampai makanan

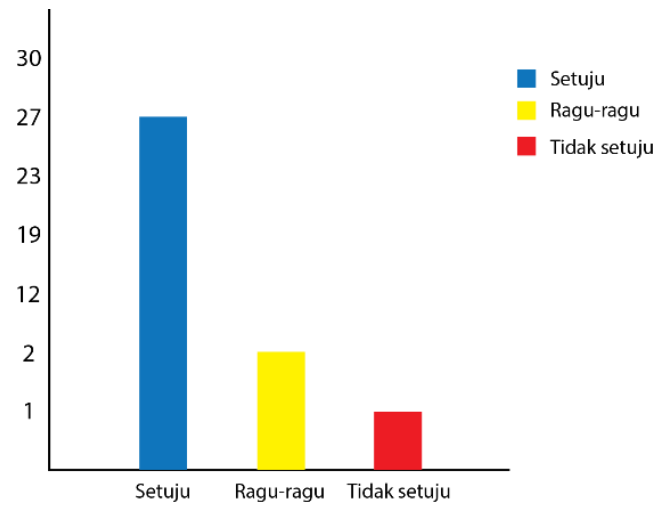

Berdasarkan tabel di atas dapat diketahui bahwa mayoritas responden menyatakan setuju yakni sebanyak 27 orang atau $90,0 \%$, sedangkan yang paling sedikit menyatakan tidak setuju yakni sebanyak 1 orang atau 3,3\%. Hasil tanggapan tersebut membuktikan mayoritas responden setuju dengan persepsi bahwa bentuk logo seperti ikon fungsi pencarian (search) melambangkan Gojek dalam memenuhi kebutuhan yang banyak dicari seperti transportasi sampai makanan.

c. Bentuk logo seperti seorang yang sedang memeluk melambangkan Gojek peduli kepada pengguna 


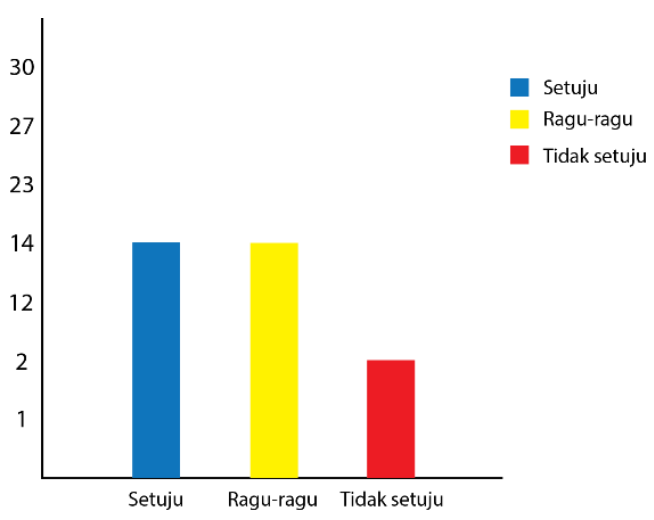

Berdasarkan tabel di atas dapat diketahui bahwa mayoritas responden menyatakan setuju dan ragu-ragu yakni sebanyak 14 orang atau $46,6 \%$, sedangkan yang paling sedikit menyatakan tidak setuju yakni sebanyak 2 orang atau $6,6 \%$. Hasil tanggapan tersebut membuktikan mayoritas responden setuju dan ragu-ragu dengan persepsi bahwa bentuk logo seperti seorang yang sedang memeluk melambangkan Gojek peduli kepada pengguna.

d. Bentuk logo menyerupai titik penanda seperti aplikasi peta digital melambangkan Gojek hadir dimanapun

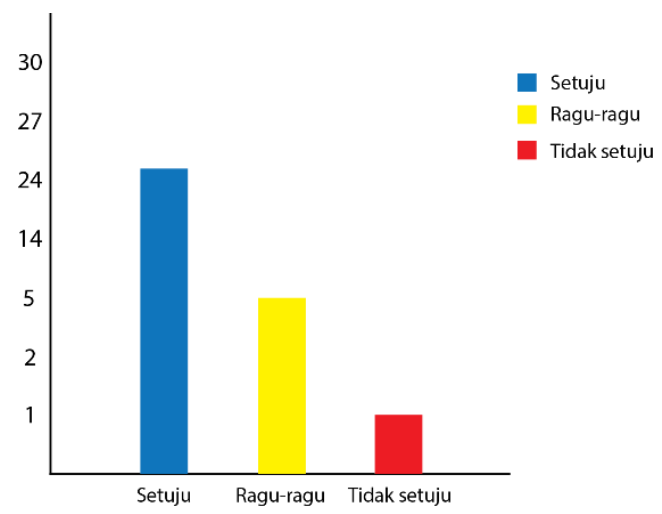

Berdasarkan tabel di atas dapat diketahui bahwa mayoritas responden menyatakan setuju yakni sebanyak 24 orang atau $80,0 \%$, sedangkan yang paling sedikit menyatakan tidak setuju yakni sebanyak 1 orang atau 3,3\%. Hasil tanggapan tersebut membuktikan mayoritas responden setuju dengan persepsi bahwa bentuk logo menyerupai titik penanda seperti aplikasi peta digital melambangkan Gojek hadir dimanapun

e. Gambar titik melambangkan driver dan lingkaran yang mengelilingi melambangkan kendaraan driver 


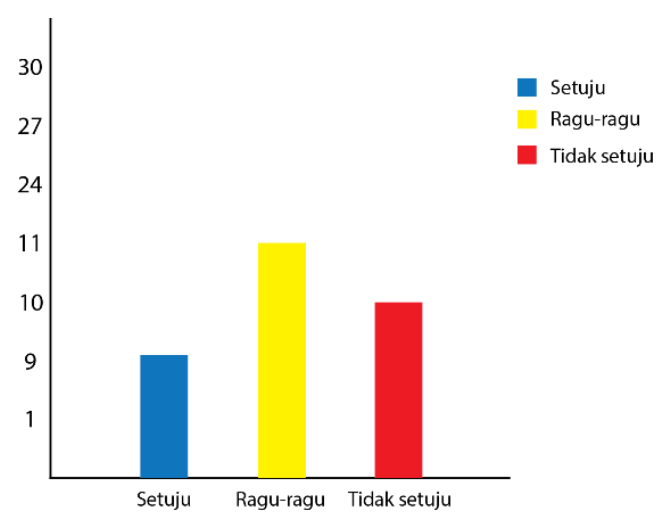

Berdasarkan tabel di atas dapat diketahui bahwa mayoritas responden menyatakan ragu-ragu yakni sebanyak 11 orang atau $36,6 \%$, sedangkan yang paling sedikit menyatakan setuju yakni sebanyak 9 orang atau 3,3\%. Hasil tanggapan tersebut membuktikan mayoritas responden ragu dengan persepsi bahwa gambar titik melambangkan driver dan lingkaran yang mengelilingi melambangkan kendaraan driver.

2. Tanggapan Dan Persepsi Stakeholder Terhadap Warna Logo

a. Warna hijau pada logo melambangkan kesegaran dan pertumbuhan, seperti Gojek yang merupakan sebuah inovasi

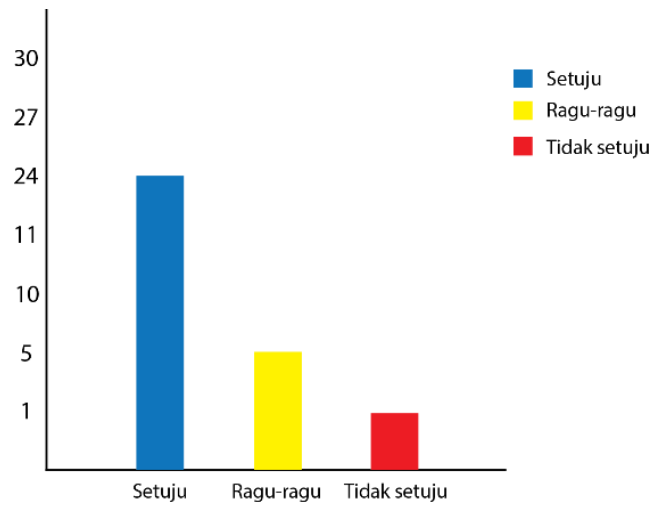

Berdasarkan tabel di atas dapat diketahui bahwa mayoritas responden menyatakan setuju yakni sebanyak 24 orang atau $80,0 \%$, sedangkan yang paling sedikit menyatakan tidak setuju yakni sebanyak 1 orang atau 3,3\%. Hasil tanggapan tersebut membuktikan mayoritas responden setuju dengan persepsi bahwa warna hijau pada logo melambangkan kesegaran dan pertumbuhan, seperti Gojek yang merupakan sebuah inovasi.

Dari hasil grafik tersebut, secara keseluruhan mayoritas stakeholder setuju dengan pernyataan yang telah diberikan. Hal ini menjadi hasil dari sebuah kajian terhadap logo Gojek Solv bahwa, logo yang mereka buat berhasil menciptakan citra yang sesuai dengan keinginan perusahan seperti Gojek sangat memberdayakan konsumennya, Gojek yang dianggap dapat memenuhi kebutuhan sehari-hari, Gojek dianggap peduli kepada penggunanya dengan selalu hadir dimanapun. Dan pada warna logo stakeholder menganggap bahwa Gojek adalah sebuah inovasi yang akan selalu tumbuh. 


\section{SIMPULAN}

Bagi perusahaan atau organisasi, logo adalah sebuah cermin dari nilai-nilai, tujuan dan identitas perusahaan. Citra perusahaan bukan hanya dibentuk dari dalam perusahaan, tetapi di luar perusahaan juga, yakni ketika perusahaan berinteraksi dengan masyarakat. Penggunaan logo bagi suatu perusahaan atau organisasi merupakan sebuah cerminan dari beberapa hal seperti, ruang lingkup kerja, visi dan misi, serta budaya perusahaan. Logo juga menjadikan suatu perusahaan memiliki perbedaan dengan pesaing di segmen pasar yang sama.

Berdasarkan hasil dari analisis tanggapan dan persepsi stakeholder terhadap sebuah identitas merek perusahaan, yaitu logo Gojek Solv, ada beberapa citra yang terbentuk dan disetujui di dalam benak stakeholder atau pelanggan. Petama, pada bentuk logo, stakeholder mengganggap bahwa Gojek sangat memberdayakan konsumennya. Gojek juga dianggap dapat memenuhi kebutuhan sehari-hari seperti transportasi sampai makanan. Selain itu, Gojek dianggap peduli kepada penggunanya dengan selalu hadir dimanapun. Kedua, pada warna logo, stakeholder menganggap bahwa Gojek adalah sebuah inovasi yang akan selalu tumbuh. Ketiga, secara keseluruhan stakeholder menggangap bahwa Gojek menghadirkan cara pintar dalam mengatasi tantangan yang dihadapi oleh para pengguna untuk hidup yang lebih mudah bagi konsumen.

Kesimpulan secara keseluruhan berdasarkan hasil analisis tanggapan dan persepsi stakeholder terhadap sebuah identitas merek perusahaan Gojek, elemen-elemen di dalam logo Gojek berhasil mewakili apa yang ingin disampaikan perusahaan. Logo Gojek berhasil menyampaikan indentitas perusahaannya sehingga tercipta citra yang baik dan sesuai di dalam benak stakeholder atau pelanggan.

\section{DAFTAR PUSTAKA}

Amajida, F. D. (2016). Kreativitas digital dalam masyarakat risiko perkotaan: Studi tentang ojek online "Gojek" di Jakarta. Jurnal Informasi, 46(1), 115-128.

Argenti, P. A. (2010). Komunikasi korporat (5th ed.). Jakarta: Salemba Humanika.

Atsar, F. (2014). Persepsi dan citra identitas visual logo Bank Mandiri. Jurnal Itenas Rekarupa, 2(1), 10-19.

Clinten, B. (2019). Filosofi di balik logo baru Gojek yang bernama "Solv". Retrieved June 17, 2020, from Kompas.com website: https://amp.kompas.com/tekno/read/2019/07/22 /14270097/filosofi-di-balik-logo-baru-Gojek-yang-bernama-solv-

Martadi, M. (2002). Reposisi citra pada logo studi kasus perubahan logo PT Pos Indonesia. Jurnal Nirmana, 4(1).

Moleong, L.J. (2007). Metode penelitian kualitatif. Bandung: Remaja Rosda Karya.

Nasution, A. D. (2017). Logo sebagai tanda: Analisis makna bentuk dan peranan warna pada hasil ciptaan para mahasiswa Polimedia Medan.

Nugrahani, F. (2014). Metode penelitian kualitatif. Solo: Cakra Books.

Sudiana, D. (1999). Ikhwal logo. Buletin Laboratorium Grafika. Fakultas Ilmu Komunikasi Universitas Padjadjaran.

Wheeler, A., \& Wheeler, A. R. (2003). Designing brand identity: A complete guide to creating, building, and maintaining strong brands. John Wiley \& Sons. 